\title{
Molekuláris citogenetikai vizsgálatok Baranya és Tolna megye plazmasejtes myelomában szenvedő betegein
}

\author{
Kosztolányi Szabolcs dr. ${ }^{1}$ - Horváth Bálint ${ }^{2}$ \\ Hosnyánszki Diána ${ }^{2}$. Kereskai László dr. ${ }^{2}$. Sziládi Erzsébet dr. ${ }^{3}$ \\ Jáksó Pál dr. ${ }^{2}$ - Alizadeh Hussain dr. ${ }^{1}$. Szuhai Károly dr. ${ }^{4}$ \\ Alpár Donát dr. ${ }^{2,5^{*}}$ - Kajtár Béla dr. ${ }^{*^{*}}$ \\ ${ }^{1}$ Pécsi Tudományegyetem, Általános Orvostudományi Kar, Klinikai Központ, I. Belgyógyászati Klinika, Pécs \\ ${ }^{2}$ Pécsi Tudományegyetem, Általános Orvostudományi Kar, Klinikai Központ, Pathologiai Intézet, Pécs \\ ${ }^{3}$ Tolna Megyei Balassa János Kórház, Hematológiai Osztály, Szekszárd \\ ${ }^{4}$ Leiden University Medical Center, Department of Cell and Chemical Biology, Leiden, The Netherlands \\ ${ }^{5}$ Semmelweis Egyetem, Általános Orvostudományi Kar, I. Patológiai és Kísérleti Rákkutató Intézet, \\ MTA-SE Lendület Molekuláris Onkohematológia Kutatócsoport, Budapest
}

\begin{abstract}
Bevezetés: A plazmasejtes myeloma változatos klinikai lefolyással járó hematológiai malignitás, melyhez heterogén genetikai háttér társul. A betegség patogeneziséhez és progressziójához asszociáltan gyakran jelennek meg visszatérő kromoszomális és szubkromoszomális eltérések, melyek diagnóziskor való kimutatása segíti a betegek genetikai karakterizálását, klasszifikációját és prognosztikai besorolását.

Célkitüzés: Tanulmányunkban átfogóan értékeltük a Pécsi Klinikai Központ és a Tolna Megyei Balassa János Kórház plazmasejtes myelomában szenvedő betegein 2005 és 2018 között általunk elvégzett molekuláris citogenetikai vizsgálatok eredményeit.

Módszer: Az említett periódusban 231 beteg csontvelői és perifériás vérmintájában szürtünk visszatérő genetikai aberrációkat fluoreszcens in situ hibridizációval. A módszerrel az immunglobulin-nehézlánc-gént érintő kromoszómatranszlokációkat, az lp és 17p kromoszómakarokat érintő vesztéseket, az lq kromoszómakart érintő többletet, valamint a 13-as kromoszómát érintő kiegyensúlyozatlan aberrációkat vizsgáltuk. Negyvenkét beteg mintáján multiplex ligatiofüggő szondaamplifikációval vizsgáltuk az lp, lq, 5q, 12p, 13q, 16q és 17p kromoszómakarok jellemző vesztéseit és többleteit. A vizsgált időszakban 116 csontvelői mintán kariotipizálásra is sor került.

Eredmények: Összesen 233 genetikai eltérést azonosítottunk célzottan, az aberrációk gyakorisága megfelelt a korábbi nemzetközi tanulmányok által látottaknak. Azonos kromoszómakarokat fluoreszcens in situ hibridizációval, valamint multiplex ligatiofüggő szondaamplifikációval vizsgálva az eredmények 96,2\%-os egyezést mutattak. Az utóbbi technikával a fluoreszcens in situ hibridizációval detektált abnormalitásokon túl további 21 kiegyensúlyozatlan genetikai aberrációt azonosítottunk 16/42 betegben (38\%).

Következtetés: Eredményeink alapján az általunk használt két molekuláris citogenetikai módszer együttes alkalmazása jelentősen segítheti a jövőben a plazmasejtes myelomában szenvedő hazai betegek átfogóbb genetikai karakterizálását.

Orv Hetil. 2019; 160(24): 944-951.
\end{abstract}

Kulcsszavak: onkohematológia, plazmasejtes myeloma, molekuláris citogenetika, FISH, MLPA

\section{Molecular cytogenetic analyses of patients with plasma cell myeloma in Tolna and Baranya counties in Hungary}

Introduction: Plasma cell myeloma is a hematological malignancy with heterogeneous genomic landscape and diverse clinical course. Recurrent chromosomal and subchromosomal aberrations commonly occur in this entity and are associated with the pathogenesis and progression of the disease. The identification of these alterations aids genetic characterization, classification and prognostication of patients.

*A. D. és K. B. közösen tervezte és felügyelte a tanulmányhoz kapcsolódó munkát. 
Aim: Molecular cytogenetic investigations of plasma cell myeloma patients treated at the University of Pécs Clinical Center and János Balassa County Hospital of Tolna County, Szekszárd, between 2005 and 2018 were evaluated in our study.

Method: 231 patients were screened for genetic aberrations using fluorescence in situ hybridization. Translocations involving the immunoglobulin heavy chain gene, losses of $1 \mathrm{p}$ and $17 \mathrm{p}$ chromosome arms, gains of lq chromosome arm and unbalanced aberrations of chromosome 13 were investigated. Losses and gains of $1 \mathrm{p}, 1 \mathrm{q}, 5 \mathrm{q}, 12 \mathrm{p}, 13 \mathrm{q}, 16 \mathrm{q}$ and $17 \mathrm{p}$ chromosome arms were analyzed using multiplex ligation-dependent probe amplification in 42 patients. During the investigated period, 116 bone marrow karyotyping was also performed.

Results: In total, 233 genetic aberrations were identified using our targeted approaches; the frequency of specific aberrations correlated with data of the recent literature. Concordance of results gained by fluorescence in situ hybridization and multiplex ligation-dependent probe amplification was $96.2 \%$ by analyzing the same chromosome arms. The latter technique revealed 21 additional genetic aberrations in $16 / 42$ patient samples (38\%) as compared to fluorescence in situ hybridization.

Conclusions: Our results suggest that the combined application of the two molecular cytogenetic methods may facilitate a more detailed characterization of genetic aberrations of plasma cell myeloma patients in Hungary.

Keywords: oncohematology, plasma cell myeloma, molecular cytogenetics, FISH, MLPA

Kosztolányi Sz, Horváth B, Hosnyánszki D, Kereskai L, Sziládi E, Jáksó P, Alizadeh H, Szuhai K, Alpár D, Kajtár B. [Molecular cytogenetic analyses of patients with plasma cell myeloma in Tolna and Baranya counties in Hungary]. Orv Hetil. 2019; 160(24): 944-951.

(Beérkezett: 2018. november 22.; elfogadva: 2018. december 9.)

\section{Rövidítések}

$\mathrm{BAC}=($ bacterial arteficial chromosome $)$ bakteriális mesterséges kromoszóma; DNS = dezoxiribonukleinsav; FISH = fluoreszcens in situ hibridizáció; $I G H=$ (immunoglobulin heavy chain gene) immunglobulin-nehézlánc-gén; IMWG = (International Myeloma Working Group) Nemzetközi Myeloma Munkacsoport; LDH = (low-density lipoprotein $)$ alacsony sűrűségű lipoprotein; MLPA = (multiplex ligation-dependent probe amplification) multiplex ligatiofüggő szondaamplifikáció; $\mathrm{PCM}=$ (plasma cell myeloma) plazmasejtes myeloma; $\mathrm{WHO}=($ Word Health Organization $)$ Egészségügyi Világszervezet

A plazmasejtes myeloma (plasma cell myeloma - PCM) terminálisan differenciált B-sejtek kóros mértékű felszaporodásával járó, jelenleg gyógyíthatatlan onkohematológiai betegség [1]. A PCM változatos genetikai hátterére jellemzőek a reciprok kromoszómatranszlokációk, a kiegyensúlyozatlan genetikai aberrációkhoz vezetó számbeli és szerkezeti (strukturális) kromoszómatöbbletek, illetve -vesztések, valamint a pontmutációk $[2,3]$. Az egyes abnormalitásoknak, illetve azok kombinációinak kimutatása segíti a PCM-ben szenvedó betegek genetikai jellemzését, klasszifikációját és prognosztikai besorolását $[4,5]$. A klinikai gyakorlat szempontjából legjelentősebb, kedvezőtlen kórlefolyással társuló genetikai aberrációk a t $(4 ; 14)(\mathrm{pl6} ; 32)(I G H-F G F R 3 / M M S E T$ génfúzió) és $(14 ; 16)(\mathrm{q} 32 ; \mathrm{q} 23)$ (IGH/MAF génfúzió) transzlokációk, valamint a TP53-gén deletiója és az l-es kromoszóma strukturális eltérései.

A kromoszomális aberrációk feltárását célzó, konvencionális citogenetikai vizsgálatok során nyert adatok ér- telmezése PCM esetében nagy óvatosságot igényel a plazmasejtek viszonylag alacsony proliferációs aktivitása miatt, mely gyakran vezet álnegatív vagy csökkent reprezentativitású eredményhez. A PCM diagnosztikájában ezért széles körben elterjedtek az interfázisban lévő sejtek magjain végzett célzott, fluoreszcens in situ hibridizációs (FISH-) vizsgálatok [6]. Bár a FISH nem alkalmas a PCM-re jellemző, gyakran komplex kromoszómaátrendeződések átfogó feltárására, feloldóképessége lehetővé teszi számos, kariotipizálással kimutathatatlan 'driver' aberráció detektálását nagyszámú sejtben, ezzel biztosítva egyedi sejtalapú, ugyanakkor magas reprezentativitású analízist. A FISH-tesztek hatékony elvégzésének leggyakrabban jelentkező akadálya a vizsgálandó myelomás csontvelő́i aspirátum vérrel való hígulása miatt bekövetkező alacsony plazmasejtarány, mely a plazmasejtek specifikus, mágnesgyöngyös dúsításával növelhető [6].

A klinikai diagnosztikában rutinszinten végzett FISHtesztekkel kettő, ritkábban három kromoszomális locus vizsgálható egyidejúleg. Emellett a tesztek egy részénél az eredmény helyes értelmezéséhez úgynevezett kontrollszonda használata is szükséges, mellyel a vizsgálni kívánt régión kívül ugyanazon kromoszóma egy távoli szakasza is láthatóvá tehetô, ezzel valójában tovább csökkentve az egyidejúleg vizsgálható célrégiók számát. A multiplex ligatiofüggő szondaamplifikáció (MLPA) olyan módszer, mellyel akár 55-60 különböző kromoszomális locus kópiaszám-eltérései is detektálhatók egy időben [7]. A módszer nem nyújt lehetőséget egyedi sejtek vizsgálatára, és megbízható használatához 25-30\%os tumorsejttisztaság szükséges, ugyanakkor exonszintú 
genomikus feloldása meghaladja a FISH tipikus, 100 kilobázis-1 megabázis nagyságrendű feloldóképességét, és a FISH-hez hasonlóan 24 órán belül eredményt szolgáltat [8]. Előnyei ellenére az MLPA széles körü alkalmazása a hazai hematológiai diagnosztikában jelenleg még várat magára.

Tanulmányunkban összesítettük több mint 200 olyan, rosszindulatú plazmasejtes kórképben szenvedő beteg molekuláris citogenetikai eredményeit, akiknek az elmúlt 13 évben diagnosztikus mintái érkeztek a Pécsi Tudományegyetem Pathologiai Intézetébe Baranya, illetve Tolna megyéből. A teljes betegpopuláción elvégzett FISH-vizsgálataink mellett a betegek egy részén teszteltük az MLPA-technika hatékonyságát is, lehetővé téve a két módszer lehetőségeinek és limitációinak közvetlen összehasonlítását.

\section{Módszer}

Tanulmányunkba a Pécsi Tudományegyetem Klinikai Központjában, valamint a Tolna Megyei Balassa János Kórház Hematológiai Osztályán, Szekszárdon, a 2005 és 2018 között plasmacytomával, plazmasejtes myelomával vagy plazmasejtes leukaemiával diagnosztizált betegeket vontuk be. A diagnózis az Egészségügyi Világszervezet (WHO), illetve a Nemzetközi Myeloma Munkacsoport (IMWG) ajánlásainak megfelelően lett meghatározva $[9,10]$; a betegek mintáinak szövettani, immunhisztokémiai, áramlási citometriai és genetikai vizsgálatai a Pécsi Tudományegyetem Pathologiai Intézetében történtek. A betegek túlnyomó többségénél csontvelői aspirátumból származó setjszuszpenziót vizsgáltunk, másoknál csak csontvelői kenet vagy cristabiopsziás minta állt rendelkezésre, míg néhány, plazmasejtes leukémiában szenvedő beteg esetén perifériás vért analizáltunk. Amennyiben a CD45, CD19, CD38, CD138 és CD56 markerekkel végzett áramlási citometriás mérés a csontvelői aspirátumban $20 \%$ alatti plazmasejtarányt igazolt, a mintán plazmasejtdúsítást végeztünk CDI38-antitesttel konjugált mágneses gyöngyökkel (BD ${ }^{\mathrm{TM}} \mathrm{IMag}$, BD Biosciences, San Jose, CA, Amerikai Egyesült Államok [USA], illetve EasySep ${ }^{\mathrm{TM}}$, STEMCELL Technologies, Vancouver, Kanada). Dúsítást követően a plazmasejtarányt Muml immuncitokémiai reakcióval ellenőriztük.

116 minta esetében csontvelői kariotipizálásra is sor került, melynek keretében plazmasejtdúsítás nélkül, 24, illetve 48 órás tenyésztést követően legalább 20 metafázis vizsgálatára került sor G-sávozásos technikával.

$\mathrm{Az}$ interfázisban lévő sejtmagokon végzett FISH-vizsgálatok során fluoreszcens szondákkal vizualizáltunk olyan genomikus locusokat, melyek a plazmasejtes myelomában jellemzően megjelenő kromoszomális aberrációk által érintettek. Kétszínú jelöléssel vizsgáltuk a 13-as kromoszóma monosomiáját, illetve hosszúkar-deletióját (Vysis LSI D13S319 SO/13q34 SG szonda, Abbott Molecular Inc., Lake Bluff, USA), a 17-es kromoszóma rövid karján mutatkozó vesztést (Vysis LSI TP53 SO/ CEP17 SG szonda), az immunglobulin-nehézlánc $(I G H)$-gént érintő átrendeződéseket (Vysis LSI IGH DC BA szonda), az utóbbi pozitivitása esetén pedig három specifikus $I G H$-transzlokációt, úgymint a $\mathrm{t}(4 ; 14)$ (p16;q32) (IGH-FGFR3/MMSET génfúzió, Vysis LSI IGH/FGFR3 DC DF szonda), a $\mathrm{t}(11 ; 14)(\mathrm{ql} 3 ; \mathrm{q} 32)$ ( IGH-CCNDI génfúzió, Vysis LSI IGH/CCNDl XT DC DF szonda) és a $\mathrm{t}(14 ; 16)(\mathrm{q} 32 ; \mathrm{q} 23)$ ( IGH-MAF génfúzió, Vysis LSI IGH/MAF DC DF szonda) átrendeződéseket. Az 1-es kromoszóma rövid karján megjelenő vesztést, illetve a hosszú karon mutatkozó többletet kereskedelemben elérhető szondával (LSI lq21 SG/ SRD lp36 SO, Kreatech Diagnostics, Amszterdam, Hollandia) és általunk létrehozott, az 1p32.2, lp21 és lq21 régiókra specifikus, bakteriális mesterséges kromoszóma (BAC-) alapú szondákkal vizsgáltuk korábban közölt protokolloknak megfelelően [11]. Az MLPA-val vizsgált betegek mintáin az MLPA-technikával látott eltérések validációjaként analizáltuk az 5-ös kromoszóma rövid és hosszú karjainak eltéréseit is (Vysis LSI EGRI SO/D5S23, D5S721 SG DC szonda). A FISH-jelek mintázatát Zeiss AxioImager Al mikroszkóppal (Carl Zeiss Technika Kft., Budapest) és háromdimenziós (3D) vizsgálatot is lehetővé tevő Zeiss Axioplan 2ie MOT motorizált citometriai múszerrel (MetaSystems, Altlussheim, Németország) értékeltük az Európai Myeloma Network ajánlásainak megfelelően [6]. Ezeknek megfelelően minden minta esetében szondakészletenként legalább 100 sejt vizsgálatára került sor; a transzlokációk esetében 10\%-os, a számbeli eltérések esetében 20\%-os küszöbértéket alkalmaztunk.

Az MLPA-reakciókhoz SALSA P425-Al szondakeveréket használtunk (MRC-Holland, Amszterdam, Hollandia); ez 42 olyan szondát tartalmazott, amelyek PCM-ben visszatérően megjelenő aberrációk által érintett kromoszomális régiókra specifikusak, úgymint lp32 (FAF1, CDKN2C, PLPP3 és DAB1 gének), lp21, lq21.3 (CKS1B-gén), lq23.3, 5q31.3, 12p13.31, $13 q 14$ ( $R B 1$ és DLEU1/DLEU2 gének), 16q12 (CYLD-gén), 16q23 (WWOX-gén) és 17pl3 (TP53gén). A reakciókat archivált sejtekből izolált DNS-mintákon, korábbi tanulmányainkból ismert módon végeztük $[11,12]$. A polimeráz-láncreakcióval képzett MLPAszonda-termékeket ABI 3730 (Applied Biosystems, Foster City, CA, USA) kapilláriselektroforézis-készülékkel szeparáltuk méretük alapján. Az elektroferogramok analízisét és a relatív kópiaszámok meghatározását a Coffalyser.Net szoftverrel (www.mlpa.com) végeztük. Genomikus többletet 1,3-nál magasabb, vesztést 0,7 -nél alacsonyabb relatív kópiaszám esetén határoztunk meg, a minta áramlási citometriával mért tisztaságát is figyelembe véve.

A FISH- és MLPA-eredményeket Fisher-féle egzakt próbával vetettük össze, SPSS 15.0 szoftvert használva (SPSS Inc., Chicago, IL, USA). 


\section{Eredmények}

Tanulmányunkban 231 beteg molekuláris citogenetikai eredményeit összesítettük. Csontvelői aspirátumot 191 betegnél tudtunk vizsgálni, csontvelőból származó kenetet 4 betegnél, további 4 betegnél perifériás vért analizáltunk, míg 32 betegnél kizárólag cristabiopsziás minta állt rendelkezésre.

A mágneses sejtdúsítás a csontvelői minták plazmasejtarányát jelentősen megemelte. 48 esetben került sor a módszer alkalmazására, amikor a plazmasejtek aránya nem haladta meg a 20\%-ot; az átlagos plazmasejtarány ezekben a mintákban $5 \%$ volt $(0,3-20,0 \%)$. A dúsítást követően átlagosan 72\%-ra emelkedett a plazmasejtek aránya (20-100\%); csupán három esetben $(6,7 \%)$ maradt az érték 30\% alatti, a dúsulás mértéke átlagosan tizennyolcszorosnak bizonyult (1. ábra). A magasabb plazmasejttartalom a FISH- és MLPA-vizsgálatok megbízható értékelését jelentősen fokozta, néhány minta esetében pedig kifejezetten a dúsítás tette lehetővé az összes genetikai vizsgálat sikeres elvégzését azáltal, hogy 30\% fölé emelte az abnormális sejtek arányát.

A 116 elvégzett csontvelői kariotipizálás közül 11 (9\%) esetben nem sikerült értékelhető metafázist nyerni, 67 (58\%) esetben klonális citogenetikai eltérés nem volt kimutatható. Nyolc (7\%) esetben a FISH-vizsgálatok során is megfigyelt eltérések igazolódtak, míg 30 (26\%) esetben a FISH-tesztek által nem vizsgált klonális aberrációk is mutatkoztak (2. ábra). Az utóbbi minták közül 17-ben (15\%) háromnál több, egymástól független eltérés is kimutatható volt, melyek közül legalább az egyik strukturális aberrációnak felelt meg (komplex kariotípus).

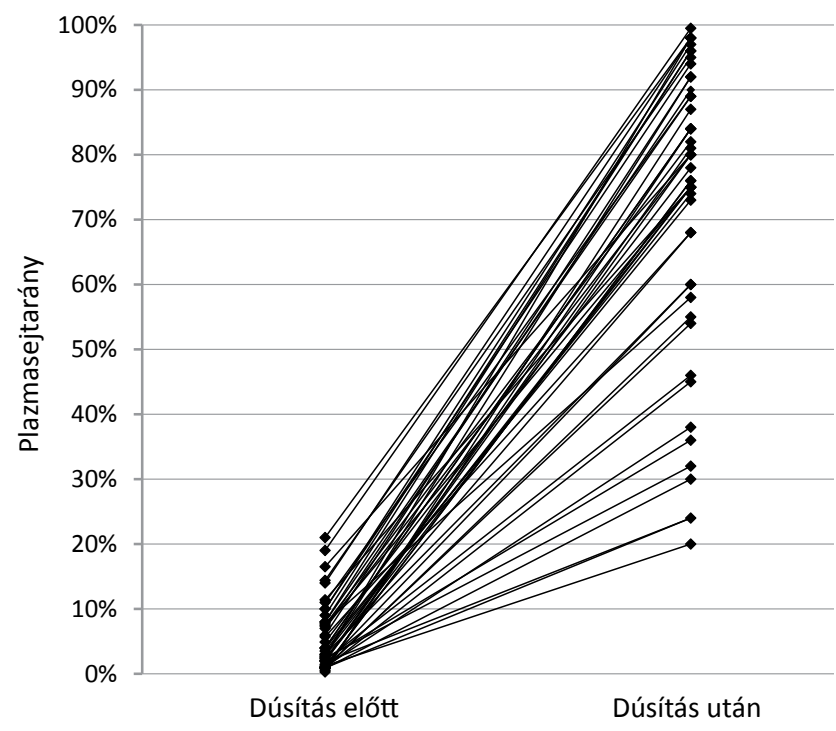

1. ábra

Plazmasejtdúsítás mágneses sejtszeparálással. 48 minta esetében mágneses sejtszeparálással átlagosan $5 \%$-os plazmasejtarányból $72 \%$-os tisztaságú sejtszuszpenziót sikerült nyerni. Valamennyi esetben $20 \%$ feletti plazmasejt-koncentrációt lehetett biztosítani a további genetikai vizsgálatok céljára

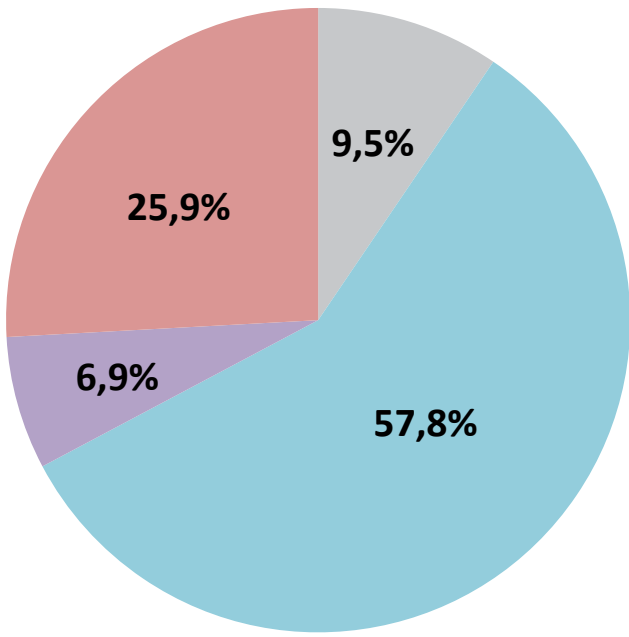

Nem informativ

Negatív

Pozitív, FISH-sel azonos

Pozitív, addicionális információ

2. ábra $\mid$ Csontvelői kariotipizálás eredményei plazmasejtes myelomában. 116 diagnosztikus minta esetében került sor kariotipizálásra, 11 esetben nem sikerült értékelhető metafázisokat nyerni, 67 esetben nem igazolódott klonális citogenetikai aberráció. Nyolc minta esetében a FISH során látottakkal azonos eltérések igazolódtak, 30 esetben $(25,9 \%)$ azonban FISH-sel nem észlelt genetikai abnormalitások is kimutathatók voltak

A teljes beteganyagon elvégzett FISH-vizsgálatok eredményeit az 1. táblázat foglalja össze. Az IGHtranszlokációt hordozó betegeken belül közel azonos gyakorisággal mutatkoztak az IGH-CCNDI (26,8\%) és az IGH-FGFR3/MMSET (24,7\%) génfúziót hordozó esetek, míg $I G H$-MAF-pozitivitást a betegek 10,7\%ában figyeltünk meg. Az lq kromoszómakar többletét, a

1. táblázat |FISH-vizsgálattal kimutatott aberrációk gyakorisága

\begin{tabular}{lc}
\hline Aberráció & Gyakoriság \\
\hline$I G H$-gén-törés & $40,7 \%$ \\
$\mathrm{t}(4 ; 14)(\mathrm{p} 16 ; \mathrm{q} 32)$ & $10,0 \%$ \\
$\mathrm{t}(11 ; 14)(\mathrm{q} 13 ; \mathrm{q} 32)$ & $11,0 \%$ \\
$\mathrm{t}(14 ; 16)(\mathrm{q} 32 ; \mathrm{q} 23)$ & $4,3 \%$ \\
$\mathrm{t}(14 ;$ ? $)(\mathrm{q} 32 ; ?)$ & $15,3 \%$ \\
$\operatorname{del}(1 \mathrm{p})$ & $8,8 \% 2$ \\
$\operatorname{gain}(1 \mathrm{q})$ & $39,8 \%$ \\
$-13 / \mathrm{del}(13 \mathrm{q})$ & $42,0 \%$ \\
del $(17 \mathrm{p})$ & $9,0 \%$ \\
\hline
\end{tabular}

${ }^{1} I G H$-transzlokációval kapcsolatban 209 beteg esetében rendelkeztünk adattal, az lp/lq strukturális eltérést 215, a 13-as kromoszóma eltérését, illetve a 17 p-deletiót 224 beteg esetében vizsgáltuk.

${ }^{2}$ Kereskedelmi forgalomban elérhető szondával nyert eredmény.

del = deletio (vesztés); FISH = fluoreszcens in situ hibridizáció; gain = többlet; $I G H$ = immunglobulin-nehézlánc-gén; $\mathrm{t}$ = transzlokáció 
13-as kromoszóma abnormalitásait, valamint a 17p kromoszómakar vesztését az irodalomban ismert gyakoriságokhoz hasonló arányban mutattuk ki, míg az lp kromoszómakar strukturális vesztése elmaradt a korábbi, DNS-microarray-alapú nemzetközi tanulmányok alapján feltételezett tartománytól. Ennek legvalószínúbb oka abban keresendő, hogy az alkalmazott, kereskedelmi forgalomban elérhető FISH-szonda az lp36 kromoszómalocust vizualizálta, míg az lp-vesztés gyakran lokalizálódik az lp32, lp31 vagy lp21 régiókra. A myeloma FISH-diagnosztikája során gyakran megjelenő jellemző aberrációs jelmintázatokat, valamint néhány általunk megfigyelt, ritkább alternatív jelmintázatot szemléltet a 3. ábra.

MLPA-módszerrel 57, DNS-vesztéssel vagy többlettel/sokszorozódással járó, kiegyensúlyozatlan aberrációt azonosítottunk 42 beteg csontvelőmintájában. A betegek több mint felében mutatkozott a 13-as kromoszómát érintő monosomia vagy strukturális vesztés, melyet csökkenő gyakorisággal követett az l-es kromoszóma hosszú karjának többlete, rövid karjának vesztése, az 5-ös kromoszóma hosszú karjának többlete, a 16-os kro-

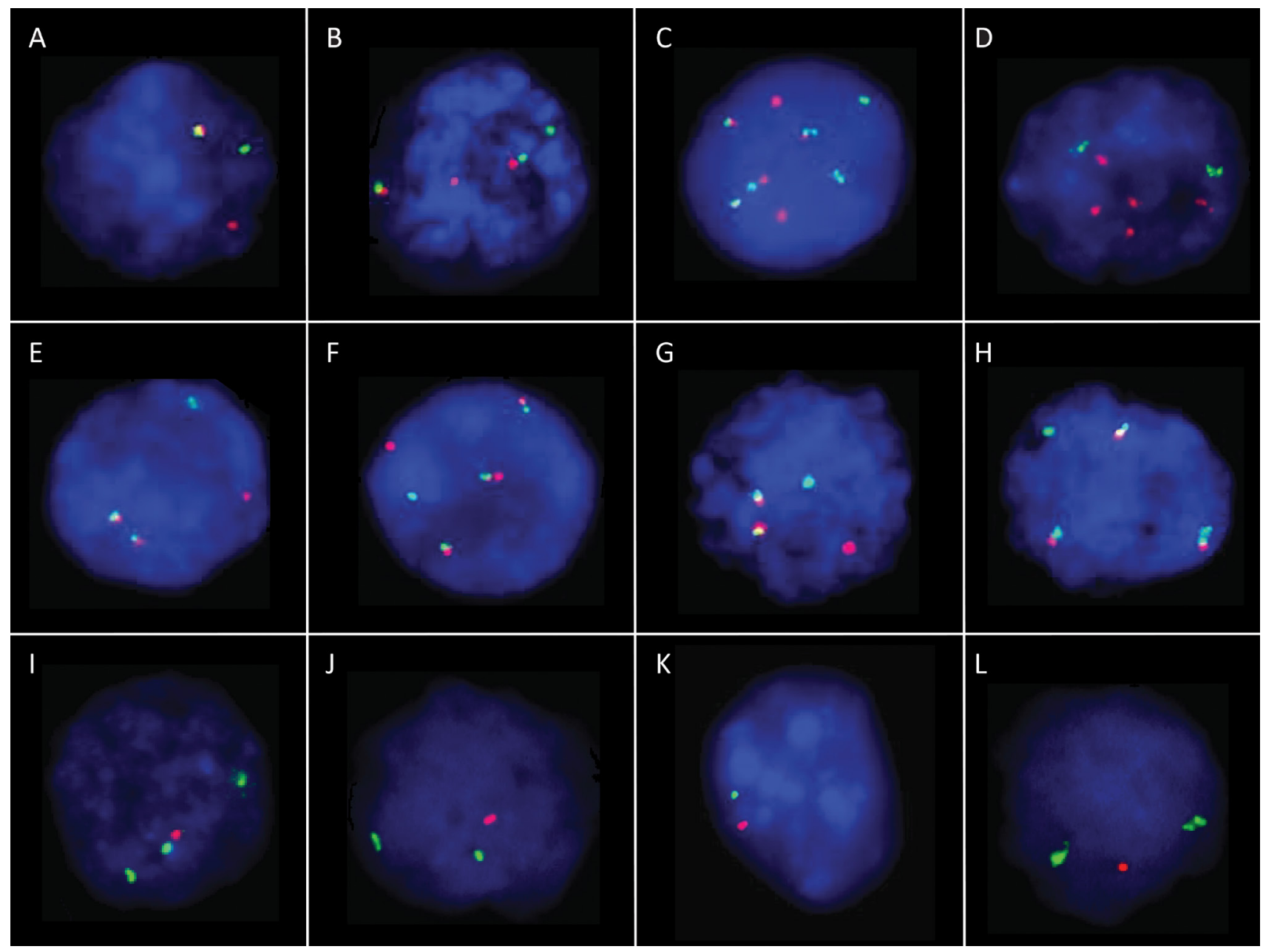

3. ábra

Abnormális FISH-jelmintázatok plazmasejtes myelomában. A) Az immunglobulin-nehézlánc (IGH)-gén törésére utaló disszociációs jelmintázat. Intakt allélok esetén a zöld és piros szondák közvetlenül egymás mellett helyezkednek el a törésponti régió két oldalán, normális sejtmagokban így a két allélnak megfelelően 2 fúziós jelet eredményezve (2F mintázat). Pozitív sejtmagokban az egyik allél interkromoszomális transzlokációja következtében a törésponttól centromerikus, illetve telomerikus irányban elhelyezkedő szondák különböző kromoszómákra helyeződnek, ezáltal térben eltávolodnak egymástól, az l fúziós (IF) mellett 1 piros (1P) és egy zöld (IZ) jelet létrehozva (IFlPlZ mintázat). B) IGH-CCNDI génfúzióhoz vezető reciprok transzlokáció a 11 -es és 14 -es kromoszómák hosszú karjai között. A duplafúziós szondakészlet nagy kiterjedésủ piros és zöld szondái a CCNDI-(1lql3), illetve az IGH-(14q32) gén törésponti szakaszait fedik le teljesen, normális sejtmagokban $2 \mathrm{P} 2 \mathrm{Z}$ jelmintázatot létrehozva. Transzlokáció esetén egy-egy piros és zöld szonda kettéhasad, a törésponttól distalisan elhelyezkedő kromoszómaszakaszok kicserélődnek, így az eltérő színú szondafragmentumok kölcsönösen egymás mellé helyeződnek, fuzionálnak (2FlP1Z mintázat). C) IGH-CCNDI génfúzió kimutatása duplafúziós szondával tetraploid kromoszómakészletű betegben $(4 \mathrm{~F} 2 \mathrm{P} 2 \mathrm{Z}$ mintázat). D) IGH-CCNDI génfúzió kimutatására irányuló vizsgálat, mely végül CCNDI-amplifikáció jelenlétét igazolta (5P2Z mintázat). E) IGH-FGFR3/MMSET génfúzióra utaló duplafúziós $2 \mathrm{~F} 1 \mathrm{P} 1 \mathrm{Z}$ jelmintázat (IGH: zöld, FGFR3: piros jel). F) $I G H$-FGFR3/MMSET-pozitivitást, valamint a fúziós gén kópiaszámnyerését igazoló 3F1P1Z jelmintázat. G) IGH-MAF génfúziót jelző, tipikus duplafúziós $2 \mathrm{~F} 1 \mathrm{PlZ}$ jelmintázat ( $I G H$ : zöld, $M A F$ : piros jel). H) IGH-MAF génfúziót, a fúziós gén kópiaszámnyerését, illetve a transzlokációban nem érintett $M A F$-allél vesztését vizualizáló, atipikus 3F1Z jelmintázat. I) lp36-locus-vesztésre (piros jel), valamint lq21-allél-nyerésre (zöld jel) utaló IP3Z jelmintázat. J) A 13-as kromoszómán bekövetkezett strukturális monoallélikus vesztés 1 P2Z jelmintázattal (13q14: piros jel, 13qter: zöld jel). K) A 13-as kromoszóma monosomiája IPlZ mintázattal. L) A 17-es kromoszómán lévő TP53-gén (piros szignál) monoallélikus hiánya, ugyanazon kromoszóma megtartott számú centromerikus régiója (zöld jel) mellett. A sejtmagok kék háttérfestését 4',6-diamidino-2-fenilindollal (DAPI) végzett teljes DNS-festés biztosította. (Objektív: 63×.) A fotók a Pécsi Tudományegyetem Pathologiai Intézetében készültek 
MLPA-vizsgálattal kimutatott aberrációk gyakorisága 42 beteg diagnosztikus mintájában

\begin{tabular}{lr}
\hline Aberráció & Gyakoriság \\
\hline $\operatorname{del}(1 p)$ & $30,9 \%$ \\
$\operatorname{gain}(1 q)$ & $45,2 \%$ \\
$\operatorname{gain}(5 q)^{*}$ & $28,6 \%$ \\
$\operatorname{del}(12 p)$ & $16,7 \%$ \\
$-13 /$ del $(13 q)$ & $52,4 \%$ \\
$\operatorname{del}(16 q)$ & $19,0 \%$ \\
$\operatorname{del}(17 p)$ & $9,5 \%$ \\
\hline
\end{tabular}

*A FISH-validálás teljes kromoszómatöbblet jelenlétét igazolta.

del = deletio (vesztés); FISH = fluoreszcens in situ hibridizáció; gain = többlet; MLPA = multiplex ligatiofüggő szondaamplifikáció

moszóma hosszú karjának vesztése, valamint a 12-es és 17-es kromoszómák rövid karjainak vesztése (2. táblázat). Emellett 3 betegben az 5q kromoszómakar vesztését, illetve 1 betegben a $16 q$ kromoszómakar többletét azonosítottuk.

Az MLPA- és FISH-eredményeket a mindkét módszerrel vizsgált 42 betegben, 5 kromoszómakar ( $1 \mathrm{p}, \mathrm{lq}$, $5 \mathrm{q}, 13 \mathrm{q}, 17 \mathrm{p}$ ) vonatkozásában tudtuk összehasonlítani. A $210(42 \times 5)$ adatpontból 202 esetben egyezett meg a vizsgálatok eredménye, ami 96,2\%-os konkordanciának felel meg (3. táblázat). Az lp kromoszómakar vizsgálatánál tapasztalt nagymértékú egyezést az ennél a 42 betegnél specifikusan validációs célból alkalmazott, BACklón-alapú FISH-vizsgálat is segítette. A 8 eltérő eredmény közül 5-nél a FISH-teszt mutatott ki pozitivitást az 1q, 5q, 13q és 17p kromoszómakarokon; az MLPA negatív eredménye nagy valószínúséggel a minták 30\%-ot meg nem haladó plazmasejttisztaságának volt köszönhető. Három esetben kizárólag az MLPA fedett fel aberrációt, két betegben az lp kromoszómakar azon régiójában, melyet egyik alkalmazott FISH-szonda sem fedett, egy betegben pedig a 17p kromoszómakar olyan rövid szakaszán mutatva ki eltérést, mely a FISH-vizsgálat feloldóképességét nem érte el. Összességében az MLPA 21 olyan aberrációt mutatott ki 16 betegben (38\%), melyek az általunk végzett FISH-vizsgálatokkal rejtve maradtak. Ugyanakkor FISH-analízissel összesen 38 olyan kiegyensúlyozott és kiegyensúlyozatlan aberrációt mutattunk ki a 42 betegben, melyeket az alkalmazott MLPA-kittel nem voltunk képesek detektálni. Továbbá, a FISH-validáció során az MLPA-teszt alapján 5q-többletnek mutatkozó aberrációk mindegyikéról kiderült, hogy valójában aneusomia, számbeli kromoszómatöbblet áll az eltérés hátterében.

\section{Megbeszélés}

A PCM terápiája jelentős fejlődésen ment keresztül az elmúlt két évtizedben, a betegek túlélési esélyei jelentősen javultak az új terápiás lehetőségeknek köszönhetően [13]. A proteoszómagátlók és immunmodulátorok kombinált, illetve egymást követő alkalmazásával a várható medián túlélés a korábbi „kemoterápiás” korszakban elérhető, átlagosan 3-4 évről 7-8 évre nőtt. Mindezek ellenére a PCM továbbra is változatos klinikai lefolyást mutat, és a betegek 15-20\%-a még mindig 2 éven belül meghal a betegség progressziója következtében [14]. A PCM kezelésének változásához szorosan társult a betegség biológiai, ezen belül genetikai hátterének alaposabb megismerése $[2,15,16]$. Számos tanulmány talált egyértelmü összefüggést a PCM változatos progressziója, klinikai lefolyása, az egyes gyógyszerek mellett észlelt terápiás válasz és az egyes betegek által mutatott eltérő genetikai háttér között [5, 17-20]. Ennek nyomán az IMWG jelenlegi ajánlásai az emelkedett LDH, csökkent szérumalbumin és magas béta-2-mikroglobulin paraméterek mellett magukban foglalják prognosztikailag meghatározónak tűnő, tipikusan FISH-sel kimutatott markerek vizsgálatát is, mint a $\operatorname{del}(17 \mathrm{p})$, a $\mathrm{t}(4 ; 14)$ és a $\mathrm{t}(14 ; 16)$, valamint újabban az 1 -es kromoszóma hosszú karjának többlete $[10,21,22]$. Ezzel összhangban a hazai hematológiai gyakorlatban is igényelt az adott esetben akár terápiás döntést is meghatározó aberrációk kimutatása, mint a $\mathrm{t}(4 ; 14)$ (IGH-FGFR3/MMSET génfúzió), a t(14;16) (IGH-MAF génfúzió) és a del(17p) (TP53-gén-vesztés); klinikai szempontból ezenkívül fontosnak tartják az lq kromoszómakar többletének, illetve az lp kar vesztésének vizsgálatát is [13].

3. táblázat |A FISH- és az MLPA-eredmények összehasonlítása

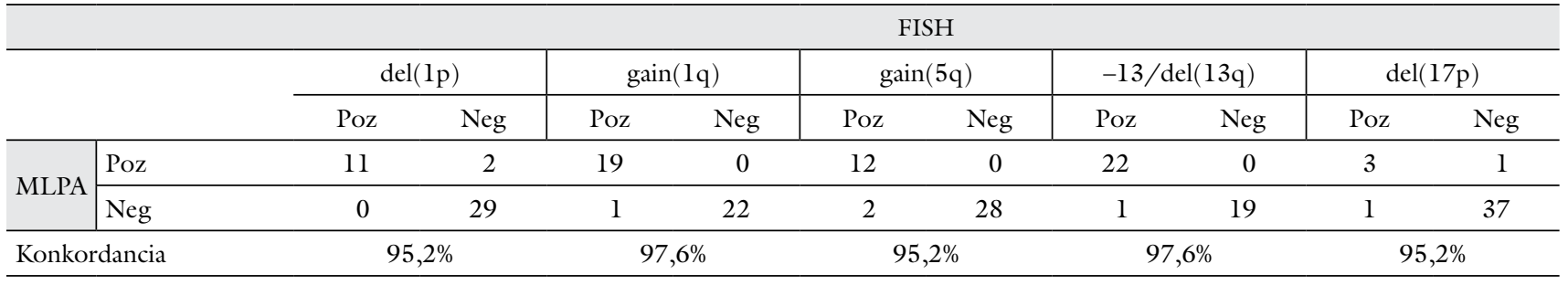

del = deletio (vesztés); FISH = fluoreszcens in situ hibridizáció; gain = többlet; MLPA = multiplex ligatiofüggő szondaamplifikáció; Neg = negatív; Poz = pozitív 
A PCM klinikai menedzsmentjének szempontjából relevánsnak gondolt genetikai aberrációk száma még mindig egyre növekvő tendenciát mutat, amire a rutin patológiai diagnosztikának bizonyos mértékben, a hazai kezelési lehetőségeket és finanszírozási kereteket is figyelembe véve, válaszolnia kell. Ezzel a szándékkal történt meg a FISH-módszer céltudatos bevezetése a PCM diagnosztikájába, mellyel a leggyakoribb kiegyensúlyozott transzlokációk és kiegyensúlyozatlan kópiaszám-eltérések specifikusan kimutathatók. A jelen tanulmányban bemutatott, több mint egy évtized alatt összegyüjtött FISH-eredmények nagymértékű egyezést mutatnak korábbi, nemzetközi tanulmányok keretében nyert adatokkal, mind a vizsgált $I G H$-transzlokációk gyakorisága, mind a kópiaszámvesztések és -többletek előfordulása tekintetében $[3,20]$. Az egyetlen kivétel ez alól az lpdeletio volt, melynek optimális vizsgálatához a jövőben alternatív szonda vagy akár több szonda párhuzamos használata is szükséges lehet az egyes betegekben előforduló aberrációk jelentősen eltérő lokalizációja miatt. Technikai szempontból elmondható, hogy a FISH egyaránt alkalmazható csontvelői aspirátumon és perifériás vérmintán, ha pedig reprezentatív mintaként csupán cristabiopsziás anyag áll rendelkezésre, szöveti körülmények között is.

A FISH-analízis lehetőségeit azonban korlátozza, hogy a kereskedelmi forgalomban elérhető szondák többsége reakciónként csak egyetlen aberráció kimutatását teszi lehetővé, a rendelkezésre álló sejtszuszpenzió/ szövetminta mennyisége pedig gyakran limitált. Ez különösen igaz olyan esetekben, amikor a minta alacsony tisztasága miatt plazmasejtdúsításra van szükség. A mágneses plazmasejt-szelekcióval nyert eddigi tapasztalataink arra utalnak, hogy a módszer valóban képes jelentősen növelni a vizsgálandó sejtszuszpenzió tisztaságát, ezáltal lehetővé téve informatív genetikai vizsgálatok elvégzését. Az eljárás azonban jelentősen csökkentheti a minta mennyiségét, ezért a betegek hatékony genetikai karakterizálásához szükség lehet olyan módszerek alkalmazására is, melyekkel több genomikus locus vizsgálható egyidejúleg.

A kariotipizálás során lehetőség nyílik a teljes genom vizsgálatára, azonban a myelomasejtek korlátozott tenyészthetôsége és in vitro sérülékenysége miatt a vizsgálat korlátozott szereppel bír a plazmasejtes myeloma diagnosztikájában. Speciális tenyésztési körülmények nélkül a vizsgálat gyakran nem reprezentatív, hiszen a mintában lévő, nem neoplasztikus vérképző sejtek gyakran túlnövik a neoplasztikus sejteket. Kariotipizálással azonban lehetőség nyílik a teljes kromoszómakészlet átfogó analízisére, ezáltal olyan eltérések is felismerhetők vele, melyek kimutatását a rutindiagnosztikában alkalmazott célzott vizsgálatok nem teszik lehetővé. A mintáink 15\%-ában észlelt komplex kariotípus megjelenése megfelel az irodalomban közölt gyakoriságnak; a jelenség plazmasejtes myelomában is kedvezőtlen prognózissal társul [23]. A fentiek értelmében a célzott módszerek használata mellett a csontvelői minták kariotipizálásának is van hozzáadott értéke a plazmasejtes myeloma genetikai diagnosztikájában.

A teljesgenom-szintű analízist biztosító, microarrayalapú és új generációs szekvenálási technikák magas költsége jelenleg nem teszi lehetővé azok széles körü alkalmazását a hazai molekuláris patológiai diagnosztikában. Az MLPA ebben a környezetben kézenfekvő alternatívának túnik költséghatékonysága, valamint viszonylag egyszerü és gyors kivitelezhetősége miatt. A módszer alkalmas a jelenlegi hazai kezelési protokollok mellett potenciális jelentőséggel bíró összes kiegyensúlyozatlan aberráció egyidejű kimutatására, ezáltal egyértelműen segíthetné a PCM-ben szenvedő magyar betegek mintáinak átfogóbb genetikai karakterizálását. Ezenkívül eredményeink alapján az MLPA genomikai feloldása néhány esetben lehetővé teheti olyan kis kiterjedésű aberrációk kimutatását is, melyek FISH-sel nem detektálhatók, igaz, a reakció elvégzéséhez a FISH-nél megszokotthoz képest valamivel magasabb mintatisztaság szükséges $(30 \%$ versus 20\%), ami a plazmasejtek mágneses dúsításával az esetek több mint 90\%-ában elérhető. Ugyanakkor a FISH képes a PCM genetikai karakterizálása szempontjából kiemelt jelentőséggel bíró kiegyensúlyozott transzlokációk kimutatására, valamint egyedi sejtszintû́ vizsgálatra, mely segíthet a myelomás sejtpopuláció betegeken belüli heterogenitásának, klonális evolúciós folyamatainak feltérképezésében [24, 25]. A kariotipizálás mellett a jövőben ezért célunk a FISH és az MLPA együttes prospektív alkalmazása folyamatosan bővülő betegpopulációnkon, valamint az így nyert citogenetikai és molekuláris citogenetikai adatbázis összevetése a betegek által mutatott klinikai manifesztációval és terápiás válasszal.

Anyagi támogatás: A közlemény megírásához kapcsolódó munkát a Nemzeti Kutatási, Fejlesztési és Innovációs Hivatal - NKFIH, K_16-119950, NVKP_16-1-20160004 és KH_17-126718 számú pályázatai, a Magyar Tudományos Akadémia Lendület Programjának LP95021. számú pályázata és Bolyai János Kutatási Ösztöndíj programja, valamint az Emberi Erőforrások Minisztériuma ÚNKP-18-4-SE-62-es kódszámú Új Nemzeti Kiválósági Programja támogatta. Az MLPA-vizsgálatokhoz a szondakeveréket az MRC-Holland bocsátotta a szerzők rendelkezésére.

Szerzôi munkamegosztás: A. D., K. B.: A tanulmány megtervezése és felügyelete. K. Sz.: Az adatok összegyuujtése és kiértékelése. H. B., H. D., K. L., Sz. E., J. P., A. H., Sz. K., A. D., K. B.: A vizsgálatok elvégzése és az adatok kiértékelése. K. Sz., A. D., K. B.: A kézirat megírása. A cikk végleges változatát valamennyi szerző elolvasta és jóváhagyta.

Érdekeltségek: A szerzőknek a közleményhez kapcsolódó közvetlen érdekeltségeik nincsenek. 


\section{Irodalom}

[1] Swerdlow SH, Campo E, Pileri SA, et al. The 2016 revision of the World Health Organization classification of lymphoid neoplasms. Blood 2016; 127: 2375-2390.

[2] Walker BA, Leone PE, Chiecchio L, et al. A compendium of myeloma-associated chromosomal copy number abnormalities and their prognostic value. Blood 2010; 116: e56-e65.

[3] Morgan GJ, Walker BA, Davies FE. The genetic architecture of multiple myeloma. Nat Rev Cancer 2012; 12: 335-348.

[4] Rajkumar SV. Multiple myeloma: 2016 update on diagnosis, risk-stratification, and management. Am J Hematol. 2016; 91: 719-734.

[5] Boyd KD, Ross FM, Chiecchio L, et al. A novel prognostic model in myeloma based on co-segregating adverse FISH lesions and the ISS: analysis of patients treated in the MRC Myeloma IX trial. Leukemia 2012; 26: 349-355.

[6] Ross FM, Avet-Loiseau H, Ameye G, et al. Report from the European Myeloma Network on interphase FISH in multiple myeloma and related disorders. Haematologica 2012; 97: 1272 1277.

[7] Hömig-Hölzel C, Savola S. Multiplex ligation-dependent probe amplification (MLPA) in tumor diagnostics and prognostics. Diagn Mol Pathol. 2012; 21 : 189-206.

[8] Kiss R, Kosztolányi S, Gángó A, et al. Multiplex ligation-dependent probe amplification in oncohematological diagnostics and research. [Multiplex ligatiofüggő szondaamplifikáció az onkohematológiai kutatásban és diagnosztikában.] Orv Hetil. 2018; 159: 583-592. [Hungarian]

[9] McKenna RW, Kyle RA, Kuehl WM, et al. Plasma cell myeloma. In: Swerdlow SH, Campo E, Harris NL, et al. (eds.) WHO Classification of tumours of haematopoietic and lymphoid tissues. Mature B-cell neoplasms: plasma cell neoplasms. 4th edn. International Agency for Research on Cancer, Lyon, 2008; pp. $202-$ 208.

[10] Rajkumar SV, Dimopoulos MA, Palumbo A, et al. International Myeloma Working Group updated criteria for the diagnosis of multiple myeloma. Lancet Oncol. 2014; 15: e538-e548.

[11] Alpar D, de Jong D, Holczer-Nagy Z, et al. Multiplex ligationdependent probe amplification and fluorescence in situ hybridization are complementary techniques to detect cytogenetic abnormalities in multiple myeloma. Genes Chromosomes Cancer 2013; 52: 785-793

[12] Kosztolányi S, Kiss R, Atanesyan L, et al. High-throughput copy number profiling by digital multiplex ligation-dependent probe amplification in multiple myeloma. J Mol Diagn. 2018; 20: 777_ 788 .
[13] Varga G, Mikala G, Váróczy L, et al. Management of multiple myeloma in Hungary in 2016. [A myeloma multiplex megközelítése Magyarországon 2016-ban.] Orv Hetil. 2016; 157: 123-137. [Hungarian]

[14] Avet-Loiseau H. Ultra high-risk myeloma. Hematology Am Soc Hematol Educ Program 2010; 2010: 489-493.

[15] Bolli N, Avet-Loiseau H, Wedge DC, et al. Heterogeneity of genomic evolution and mutational profiles in multiple myeloma. Nat Commun. 2014; 5: 2997.

[16] Walker BA, Boyle EM, Wardell CP, et al. Mutational spectrum, copy number changes, and outcome: results of a sequencing study of patients with newly diagnosed myeloma. J Clin Oncol. 2015; 33: 3911-3920.

[17] Avet-Loiseau H, Li C, Magrangeas F, et al. Prognostic significance of copy-number alterations in multiple myeloma. J Clin Oncol. 2009; 27: 4585-4590.

[18] Jacobus SJ, Kumar S, Uno H, et al. Impact of high-risk classification by FISH: an Eastern Cooperative Oncology Group (ECOG) study E4A03. Br J Haematol. 2011; 155: 340-348

[19] Kumar S, Fonseca R, Ketterling RP, et al. Trisomies in multiple myeloma: impact on survival in patients with high-risk cytogenetics. Blood 2012; 119: 2100-2105.

[20] Manier S, Salem KZ, Park J, et al. Genomic complexity of multiple myeloma and its clinical implications. Nat Rev Clin Oncol. 2017; 14: 100-113.

[21] Chng WJ, Dispenzieri A, Chim CS, et al. IMWG consensus on risk stratification in multiple myeloma. Leukemia 2014; 28: 269277.

[22] Sonneveld P, Avet-Loiseau H, Lonial S, et al. Treatment of multiple myeloma with high-risk cytogenetics: a consensus of the International Myeloma Working Group. Blood 2016; 127: 2955-2962.

[23] Nemec P, Zemanova Z, Kuglik P, et al. Complex karyotype and translocation $\mathrm{t}(4 ; 14)$ define patients with high-risk newly diagnosed multiple myeloma: results of CMG2002 trial. Leuk Lymphoma 2012; 53: 920-927.

[24] Nagy Z, Kajtár B, Jáksó P, et al. Evolutionary sequence of cytogenetic aberrations during the oncogenesis of plasma cell disorders. Direct evidence at single cell level. Leuk Res. 2011; 35: 1114-1116.

[25] Keats JJ, Chesi M, Egan JB, et al. Clonal competition with alternating dominance in multiple myeloma. Blood 2012; 120: 1067-1076.

(Kajtár Béla dr., Pécs, Szigeti út 12., 7624 e-mail: belakajtar@yahoo.com)

A cikk a Creative Commons Attribution 4.0 International License (https://creativecommons.org/licenses/by/4.0/) feltételei szerint publikált Open Access közlemény, melynek szellemében a cikk bármilyen médiumban szabadon felhasználható, megosztható és újraközölhető, feltéve, hogy az eredeti szerző és a közlés helye, illetve a CC License linkje és az esetlegesen végrehajtott módositások feltüntetésre kerülnek. (SID_1) 